\title{
ASSESSING THE ECONOMIC RESILIENCE OF THE POOR AND VULNERABLE GROUPS EAST JAVA PROVINCE IN THE MIDDLE OF THE COVID-19 PANDEMIC : SUSENAS DATA STUDY 2019
}

\author{
Herman Palani*1 ${ }^{*}$ \\ Ahmad Zufar Robbani ${ }^{2}$ \\ ${ }^{1,2}$ Kementerian Perencanaan Pembangunan Nasional/Bappenas, Indonesia
}

\begin{abstract}
The COVID-19 pandemic has had a significant economic impact, especially on the poor and vulnerable groups in East Java, which is one of the provinces most affected by this pandemic. However, studies that focus on assessing the level of economic resilience of the poor and vulnerable groups in East Java are still limited. This study was conducted to analyze the economic resilience of the poor and vulnerable groups in East Java in terms of various characteristics such as access to social safety nets, asset ownership, savings account ownership, employment sector, and access to public facilities. Using Susenas data as the main data source and quantitative descriptive analysis method, this study shows that the poor and vulnerable groups have low resilience, limited access to social safety nets and low self-defense systems are two important factors that affect resilience levels. will be used to evaluate existing policies and provide recommendations for future policy improvements.
\end{abstract}

Keywords: Covid-19, East Java, Poor Group, Vulnerable Group, Resilience

\section{ABSTRAK}

Pandemi covid-19 telah memberikan dampak ekonomi yang signifikan, utamanya terhadap kelompok miskin dan rentan di Jawa Timur yang merupakan salah satu provinsi yang paling terdampak akibat pandemi ini. Namun demikian, studi yang fokus untuk menilai tingkat ketahanan ekonomi dari kelompok miskin dan rentan di Jawa Timur masih terbatas. Penelitian ini dilakukan untuk menganalisis ketahanan ekonomi dari kelompok miskin dan rentan di Jawa Timur dilihat dari berbagai karakteristik seperti akses ke jaring pengaman sosial, kepemilikan aset, kepemilikan rekening tabungan, sektor pekerjaan, dan akses terhadap fasilitas publik. Dengan menggunakan data Susenas sebagai sumber data utama dan metode analisis deskriptif kuantitatif penelitian ini menunjukkan bahwa kelompok miskin dan rentan memiliki relisiensi yang rendah, terbatasnya akses ke jaring pengaman sosial dan sistem pertahanan diri yang rendah menjadi dua faktor penting yang mempengaruhi tingkat resiliensi.Temuan ini juga akan digunakan untuk mengavaluasi kebijakan yang sudah ada dan memberikan rekomendasi perbaikan kebijakan ke depannya.

Kata kunci: Covid-19, Jawa Timur, Miskin, Rentan, Resiliensi

JEL : I15, I30, 011 


\section{Pendahuluan}

Krisis Covid-19 telah membuat banyak perlambatan tidak hanya pada sektor ekonomi tetapi juga berbagai sektor lainnya. Perlambatan ini sejalan dengan semakin meningkatnya penyebaran virus Covid-19 di berbagai negara. Hingga 23 September 2020 terdapat 31,85 juta kasus di seluruh dunia. Indonesia berada di peringkat 23 dari 215 negara dengan 257.388 kasus (Worldometer, 2020). Melihat persebaran kasus nasional, Provinsi Jawa Timur menjadi salah satu provinsi dengan kasus terbanyak. Sebanyak 16,22\% (40.755) kasus nasional tersebar di Provinsi Jawa Timur (Kawalcovid19, 2020). Oleh karena itu wilayah Jawa Timur menjadi salah satu prioritas penanganan Covid-19 di tanah air.

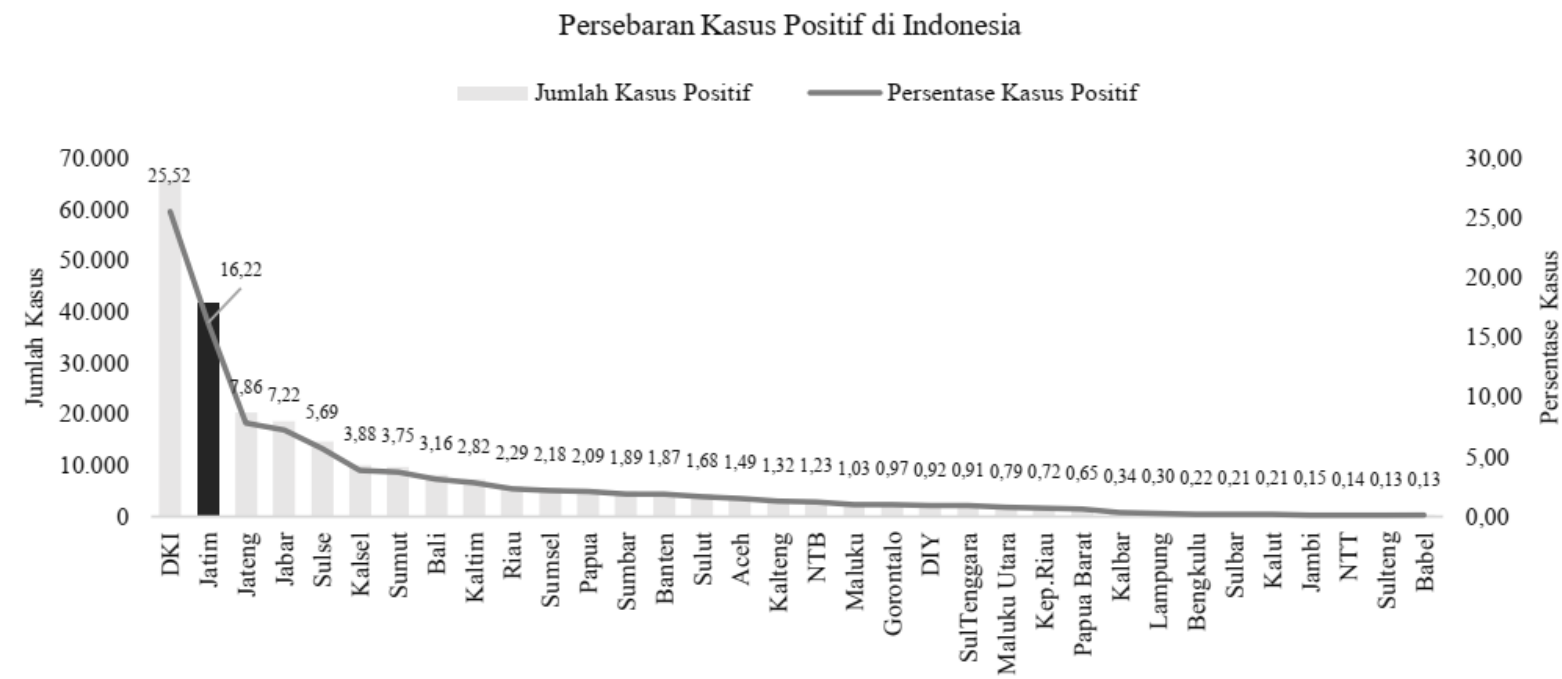

Sumber: Kawalcovid.19.id, data per 23 September 2020 data diolah

\section{Gambar 1: Persebaran Kasus Positif di Indonesia}

Pandemi Covid-19 telah mempengaruhi berbagai sektor dalam perekonomian dan kehidupan sosial. Pertumbuhan ekonomi Indonesia pada triwulan II tercatat -5,32\% (yoy), terparah sejak krisis 1998. Sejalan dengan apa yang terjadi di tingkat nasional, pertumbuhan ekonomi Jawa Timur pun terkontraksi sebesar 5,90\%, menurun lebih tinggi dibandingkan pertumbuhan ekonomi nasional. Covid-19 juga mempengaruhi pekerjaan 3,5 juta karyawan di sektor formal dan informal yang terpaksa di-PHK dan dirumahkan. Lebih lanjut, penelitian menunjukkan bahwa dalam proyeksi terberat, angka kemiskinan akan meningkat menjadi $12,4 \%$, yang berarti akan ada 8,5 juta penduduk miskin baru (Suryahadi dkk., 2020).

Situasi ini menuntut pemerintah bekerja luar biasa dalam mitigasi pandemi Covid-19 sekaligus mengurangi dampak sosial yang ditimbulkan. Berbagai paket kebijakan dikeluarkan bersamaan dengan stimulus sejumlah Rp695,2 triliun (US\$46,89 miliar). Stimulus ini digunakan untuk penanganan pandemi Covid-19 dan program pemulihan ekonomi nasional (PEN). Jumlah stimulus kesehatan mencapai Rp87,55 triliun, program jaring pengaman sosial sebesar Rp203,9 triliun, stimulus dan bantuan untuk usaha mikro kecil menengah (UMKM) sebesar Rp 123,46 triliun, dan sisanya digunakan untuk pembiayaan korporasi dan dana sektoral untuk kementerian/lembaga dan pemerintah daerah.

Selain adanya paket kebijakan nasional, berbagai daerah juga bergerak dengan programnya masing-masing termasuk Provinsi Jawa Timur. Untuk percepatan pemulihan ekonomi, Jatim mengeluarkan bantuan senilai Rp23,725 miliyar untuk pemberdayaan usaha perempuan, Rp5 miliyar untuk BUMDES, bantuan kredit dana bergulir (dagulir) bagi pelaku 
UMKM sebesar Rp330 miliyar, dan suplemen bantuan untuk program Bantuan Pangan Non Tunai (BPNT) sebesar 50\% dari yang sudah dianggarkan oleh pemerintah pusat.

Terlepas dari berbagai program pemulihan ekonomi dan bantuan sosial sebagai jaring pengaman sosial baik yang dilakukan pemerintah pusat dan daerah, efektivitas dari bantuan tersebut jauh lebih penting dibandingkan dengan nominalnya. Artinya, program-program yang ada harusnya tepat sasaran dan menyasar orang-orang yang memang membutuhkan. Fakta di lapangan ternyata masih ditemukan inclusion dan exclusion error yang dapat mengurangi efektivitas dari program.

Pentingnya efektivitas dari berbagai program pemerintah ditenggarai oleh jumlah penduduk yang terdampak Covid-19 terbilang besar. Salah satu kelompok yang paling terdampak baik konsumsi maupun pendapatannya adalah kelompok miskin (poor) dan rentan (vulnerable). Oleh karenanya apabila program yang ada tidak efisien dan efektif maka akan menimbulkan permasalahan sosial yang lebih serius seperti, kelaparan dan tindakan kriminalitas.

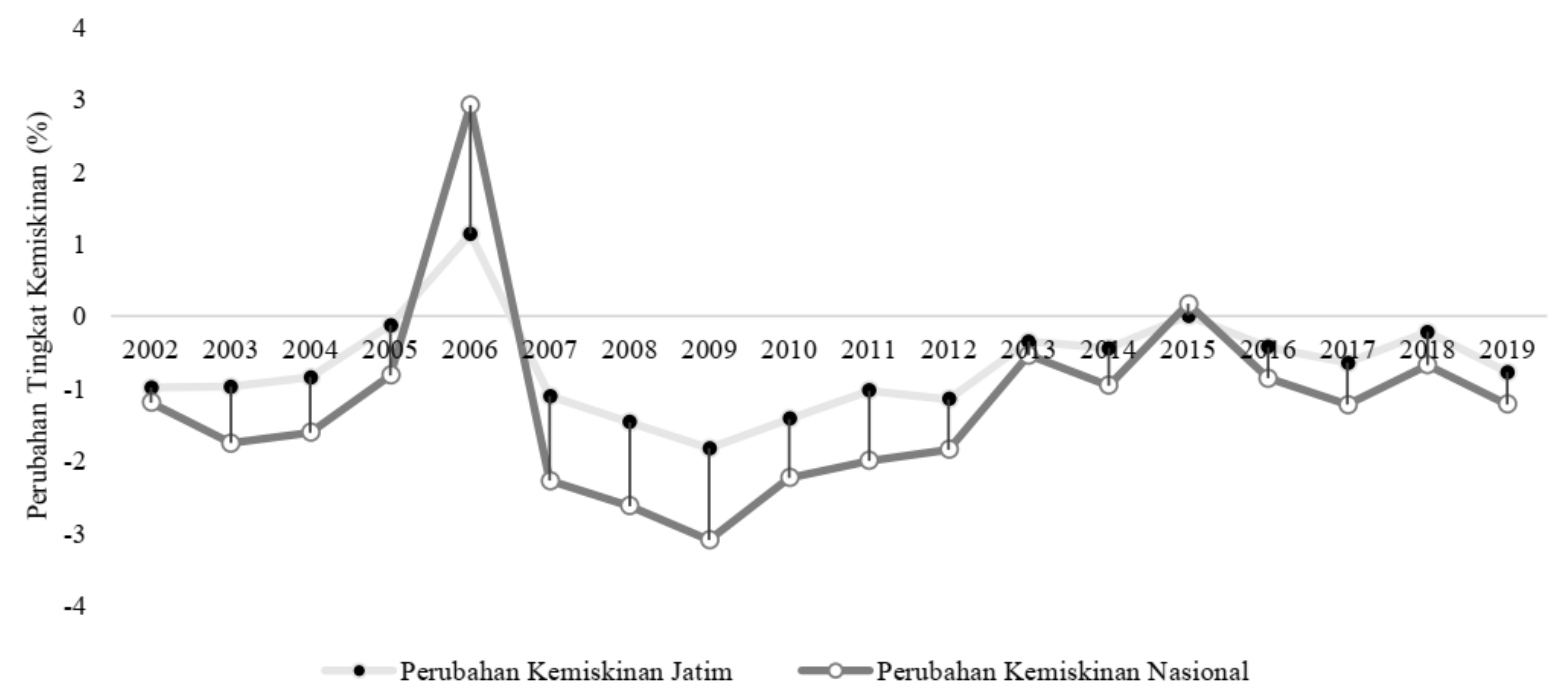

Sumber: Badan Pusat Statistik, 2019 data diolah

Gambar 2: Perubahan Tingkat Kemiskinan Nasional dan Jawa Timur 2002-September 2020

Proyeksi Suryahadi dkk (2020) terkait tingkat kemiskinan nasional di atas dapat digunakan untuk memberikan gambaran terkait tingkat kemiskinan di Jawa Timur. Pasalnya, pola perubahan tingkat kemiskinan nasional tidak jauh berbeda dengan apa yang terjadi di Jawa Timur (lihat gambar 2). Rerata perbedaan perubahan (ditunjukkan pada garis jarak antara perubahan tingkat kemiskinan nasional dan Jawa Timur) adalah sebesar $0,30 \%$ yang artinya interval perbedaan data nasional dan Jawa Timur bisa kurang 0,30\% atau lebih 0,30\%. Sementara proyeksi kemiskinan oleh Suryahadi dkk (2020) dalam skenario berat adalah dari 9,2\% menjadi 9,7\% (akhir tahun 2020), dan dalam skenario terberat meningkat menjadi $12,4 \%$ (akhir tahun 2020), maka potensi kemiskinan Jawa Timur dapat dilihat pada tabel 1.

Dengan menggunakan proyeksi dari Suryahadi dkk (2020) dan diimplementasikan ke data Provinsi Jawa Timur, maka diketahui bahwa Jawa Timur cukup rentan dalam hal kemiskinan (lihat tabel 1). Pada skenario berat saja setidaknya diproyeksikan terdapat 79 ribu -317 ribu lebih penduduk miskin baru, dan jika kondisi semakin parah maka tidak menutup kemungkinan Jawa Timur akan menghadapi skenario terberat dengan 1,1 juta - 1,34 juta lebih penduduk miskin baru yang harus ditangani. 
Tabel 1: Potensi Peningkatan Kemiskinan Provinsi Jawa Timur

\begin{tabular}{lcccc}
\hline Skenario & $\begin{array}{c}\text { Peningkatan } \\
\text { kemiskinan } \\
\text { nasional }\end{array}$ & $\begin{array}{c}\text { Peningkatan kemi- } \\
\text { skinan Jawa Timur } \\
\text { (interval 0,30\%) }\end{array}$ & $\begin{array}{c}\text { Tingkat kemiskinan } \\
\text { jawa timur akhir } \\
\text { tahun 2020 }\end{array}$ & $\begin{array}{c}\text { Jumlah penduduk mi- } \\
\text { skin baru Jawa Timur } \\
\text { tahun 2020 (dalam } \\
\text { jiwa) }\end{array}$ \\
\hline $\begin{array}{l}\text { Skenario Berat } \\
(9,2 \%-9,7 \%)\end{array}$ & $0,5 \%$ & $0,20 \%-0,80 \%$ & $10,4 \%-10,11 \%$ & $79.397-317.589$ \\
\hline $\begin{array}{l}\text { Skenario Terberat } \\
(9,2 \%-12,4 \%)\end{array}$ & $3,1 \%$ & $2,80 \%-3,4 \%-$ & $-13,00 \%-13,60 \%$ & $1.111 .561-1.349 .753$ \\
\hline \begin{tabular}{l} 
Sumber: Estimasi penulis diolah dari data BPS (2020) \\
\hline
\end{tabular}
\end{tabular}

Berbagai proyeksi seperti yang dijelaskan di atas telah dilakukan baik di tingkatan global, negara, maupun daerah. Proyeksi yang dikeluarkan sebagian besar baru sebatas persentase total penambahan, dan total keseluruhan (Albert, dkk., 2020; Suryahadi dkk., 2020; Martin dkk., 2020). Hanya saja studi-studi yang menggali lebih dalam tingkat kerentanan kelompok miskin dan rentan (poor and vulnerable) di tengah Covid-19 masih sangat terbatas. Kemudian analisis mengenai karakteristik kelompok miskin dan rentan dan keterlibatan mereka dalam program pemerintah (bantuan sosial dan partisipasi ekonomi) di tengah pandemi juga masih belum banyak dilakukan.

Berangkat dari masalah dan fakta di atas penelitian ini bertujuan untuk menilai atau mengukur relisiliensi (ketahanan) rumah tangga di Jawa Timur di tengah pandemi Covid-19. Penilaian ini akan melihat berbagai karakteristik kelompok kelas konsumsi di Jawa Timur yang kemudian dianalisis untuk melihat tingkat kerentanannya. Penilaian ini juga melihat kemiskinan multidimensi yang ada di Jawa Timur. Selain itu, penelitian ini juga bertujuan untuk melihat tingkat efektivitas program baik program pemerintah pusat maupun pemerintah daerah dalam memitigasi dampak Covid-19. Dengan menggunakan metode deksriptif kuantitatif penelitian ini menemukan bahwa kelompok miskin dan rentan memiliki tingkat resiliensi yang rendah. Hal ini tercermin dari empat indikator yakni jaring pengaman sosial, sektor pekerjaan, akses terhadap layanan publik, aset, dan pendapatan dan akses pangan. Penelitian juga mendiskusikan bagaimana relevansi hasil temuan dengan kebijakan penanganan krisis Covid-19 yang sedang berjalan.

\section{Tinjauan Pustaka}

\section{Memahami Konsep Ketahahan Rumah Tangga dan Kelompok Rentan}

\section{Ketahanan Rumah Tangga (Household Resilience)}

Pada awalnya konsep resiliensi (ketahanan) banyak digunakan pada literatur kelingkungan (ecological) (Holling, 1973). Namun, konsep tersebut meluas sampai ke bidang ekonomi pembangunan dan salah satunya adalah kajian sosioekonomi (Levin dkk., 1998). Konsep ini berguna dalam mengevaluasi sistem sosial dikarenakan menyediakan analisis dan pengukuran dari sistem yang berkelanjutan. Lebih lanjut, resiliensi dilihat sebagai kapasitas untuk menyelesaikan persolan, tidak hanya itu resiliensi juga mengorganisasi ulang sebuah sistem dikarenakan adanya perubahan yang sedang berlangsung (Walker dkk., 2004; Folke, 2006). Konsep relisiensi sangat erat hubunganya dengan konsep kerentanan (vulnerability). Seseorang yang yang rentan dalam sebuah situasi harus mempunyai ketahanan yang baik jika tidak mau tertelan oleh situasi tersebut.

Menurut Dercon (2001) rumah tangga atau individu mempunya aset seperti, tenaga kerja, modal manusia, modal fisik, dan modal sosial digunakan untuk bertahan hidup. Aset 
digunakan untuk menciptakan pendapatan, dan pendapatan digunakan untuk mengakses kesejahteraan (well-being) yang berupa konsumsi, akses nutrisi, akses kesehatan, dan lainlain. Dari framework ini kita tahu bahwa kesejahteraan seperti ketahanan pangan atau tingkat kemiskinan adalah hasil dari keputusan atas penggunaan aset dan pendapatan ketika menghadapi risiko. Jika alokasi penggunaannya tidak tepat atau terdapat proses terganggu yang terjadi di dalamnya maka akan berdampak pada kerentanan.

Tabel 2: Framework Resiliensi rumah tangga

\begin{tabular}{lll}
\hline \multicolumn{1}{c}{ Aset } & \multicolumn{1}{c}{ Pendapatan } & \multicolumn{1}{c}{ Kesejahteran } \\
\hline Modal manusia, tenaga kerja & Imbal hasil dari pekerjaan dan aset & Konsumsi \\
\hline Modal fisik/keuangan & Tabungan, kredit, dan investasi, dll & Nutrisi \\
\hline Commons good/public goods & & Kesehatan \\
\hline Modal sosial & & Pendidikan \\
\hline
\end{tabular}

Sumber: Dercon (2001)

FAO (2009) memberikan gambaran yang baik dalam penelitiannya mengenai resiliensi pada kelangkaan pangan yang dapat digunakan untuk menilai resiliensi pada variabel lainnya. FAO (2009) mengandaikan rumah tangga pada awalnya berapada di $T_{0}$, lalu terjadi shock (endogenoes shock atau exogenous shock), kemudian rumah tangga akan merespon shock tersebut sesuai dengan kapasitasnya, sebagian respon yang lain akan dilakukan oleh pemerintah. Tingkat resiliensi rumah tangga akan ditentukan tingkat adaptivitas dan tingkat stabilitas dari rumah tangga tersebut. Kerangka berikut akan lebih memberikan gambaran umum bagaimana mekanisme resiliensi rumah tangga.
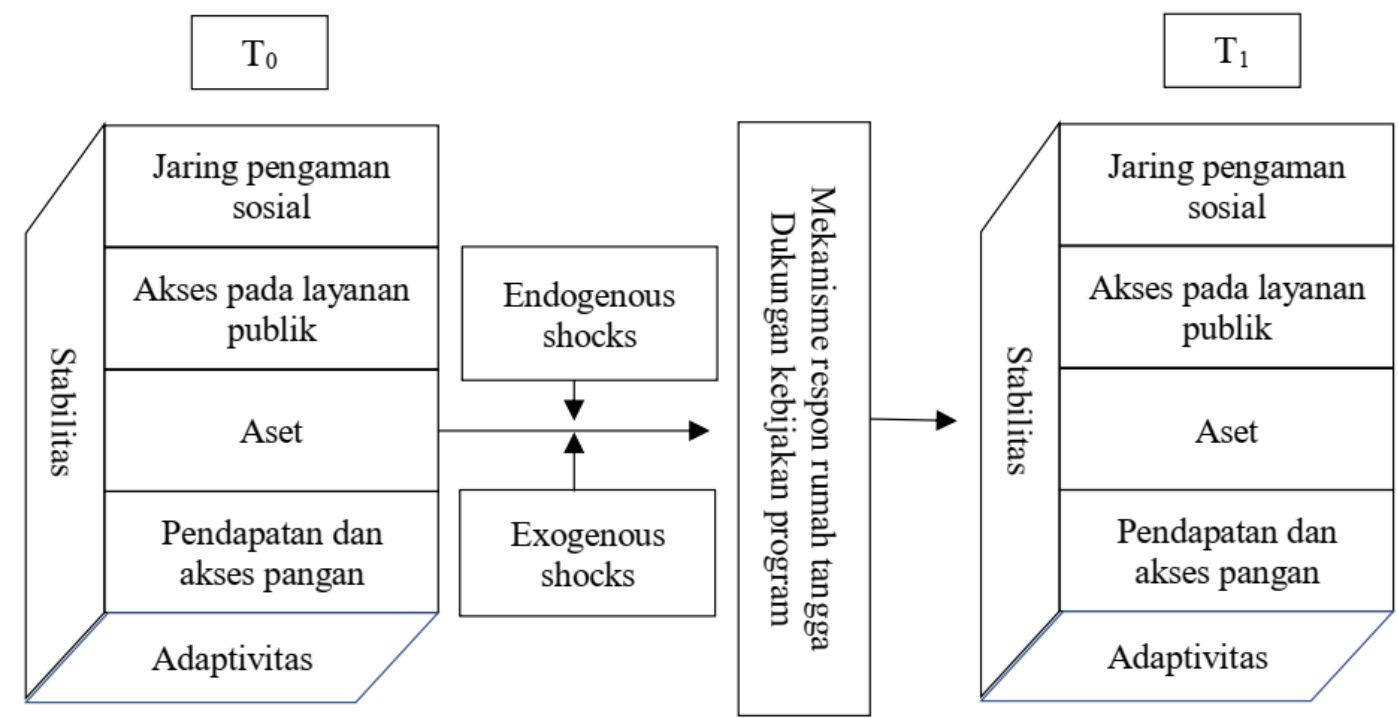

Sumber: FAO (2009)

\section{Gambar 3: Konsep Resiliensi Rumah Tangga}

Setiap komponen pada $T_{0}$ diestimasi secara terpisah untuk memperoleh indeks komposit dari resiliensi rumah tangga. Komponen yang ada di $\mathrm{T}_{1}$ akan mereflesikan bagaimana semua faktor-faktor tersebut mengubah resiliensi rumah tangga. Proses ini dapat dituliskan dalam persamaan berikut untuk melihat indeks resiliensi rumah tangga $i$.

$$
R_{i}=f\left(I F A_{i}, A_{i}, A P S_{i}, S S N_{i}, S_{i}, A C_{i}\right)
$$


dimana

$R \quad=$ Resilience (Resiliensi)

$S \quad=$ Stability (Stabilitas)

$S S N=$ Social Safet Net (Jaring Pengaman Sosial)

$A P S=$ Access to Public Services (Akses ke layanan publik)

$A \quad=$ Assets (Aset)

IFA = Income and food access (Pendapatan dan akses terhadap pangan)

$A C \quad=$ Adaptive capacity (Kapasitas beradaptasi)

Kelompok Rentan (Vulnerable Group)

Kelompok rentan adalah mereka yang tidak terpapar dampak secara langsung tetapi siapa pun yang masuk dalam kelompok ini bisa berubah-ubah dengan sangat dinamis Seseorang yang tidak dianggap rentan pada saat pandemi atau pun bencana lainnya dapat menjadi rentan tergantung dengan respon pemerintah dalam menghadapi bencana. Di tengah pandemi Covid-19, kelompok rentan tidak hanya mereka yang sudah berumur, mempunyai penyakit bawaan (komorbit), atau tidak punya tempat tinggal (homeless), tetapi juga mereka yang berasal dari berbagai lapisan ekonomi yang mungkin sedang berjuang secara finansial, mental, atau pun fisik (The lancet, 2020). Lebih spesifik, kelompok rentan di tengah pandemi Covid-19 dapat dibagi menjadi dua yakni, 1. Rentan secara kesehatan: orangtua, orang dengan penyakit bawaan, dan disabilitas (Smith \& Judd, 2020). 2. Rentan secara ekonomi: kelompok kelas menengah ke bawah, kelompok perempuan, dan lain-lain (Voa Indonesia, 2020). Kelompok yang rentan secara ekonomi ini sebagian besar disebut dengan pekerja rentan yang mereka bekerja tidak menentu (kontrak, jam kerja, jaminan yang tak tentu, lingkup yang tak menentu) (Standing, 2011). Pekerja rentan bukan hanya mereka yang bekerja informal tetapi juga mereka yang berada dalam ketidakpastian ekonomi.

Dalam konteks pandemi, sulit bagi kelompok (pekerja) rentan untuk mematuhi apa yang direkomendasikan oleh pemerintah seperti, bekerja dari rumah, menjaga jarak, dan protokol kesehatan lainnya. Sebab, sulit bagi pekerja rentan untuk bekerja dari rumah dengan skill yang rendah, dan juga penghasilan mereka juga sebagian besar adalah penghasilan harian. Lalu, kelompok rentan juga sulit untuk selalu mematuhi protokol kesehatan dikarenakan keadaan sosial ekonomi yang tidak mendukung. Bagi masyarakat miskin tidak mudah untuk mendapatkan akses air bersih dan sanitasi yang baik, selain itu akses mereka untuk makanan yang sehat dan bernutrisi juga sangat terbatas. Dampak dari keadaan ekonomi ini juga berdampak pada anak-anak di dalam rumah tangga tersebut. Di India, anak-anak menjadi rentan dikarenakan orangtuanya di-PHK atau tidak bisa bekerja dari rumah. Lebih dari $80 \%$ tenaga kerja di India bekerja di sektor informal, dan lockdown yang dilakukan oleh pemerintah telah berdampak besar terhadap peningkatan pengangguran di negara tersebut. Alhasil, rumah tangga yang kehilangan pekerjaan pasti akan sangat terdampak secara sosioekonomi (The Lancet, 2020).

Di antara rumah tangga yang terdampak tersebut, terdapat kelompok yang terdampak berat atau pun ringan tergantung sektor pekerjaannya. Badan Pusat Statistik merilis laporan mengenai sektor mana saja yang mengalami kontraksi atau pun tidak selama kuartal II tahun 2020. Gambar 4 menunjukkan bahwa sektor tranportasi dan pergudangan terdampak paling parah pada PDB triwulan II 2020 yakni --30,84\%, disusul sektor akomodasi dan makan minum $(-22,02 \%)$, jasa lainnya $(-12,60 \%)$, perdagangan $(-7,57 \%)$, dan industri $(-6,19 \%)$. Oleh karenanya penting untuk melihat data pekerja pada sektor-sektor tersebut dikarenakan terdapat potensi PHK atau dirumahkan sementara. 


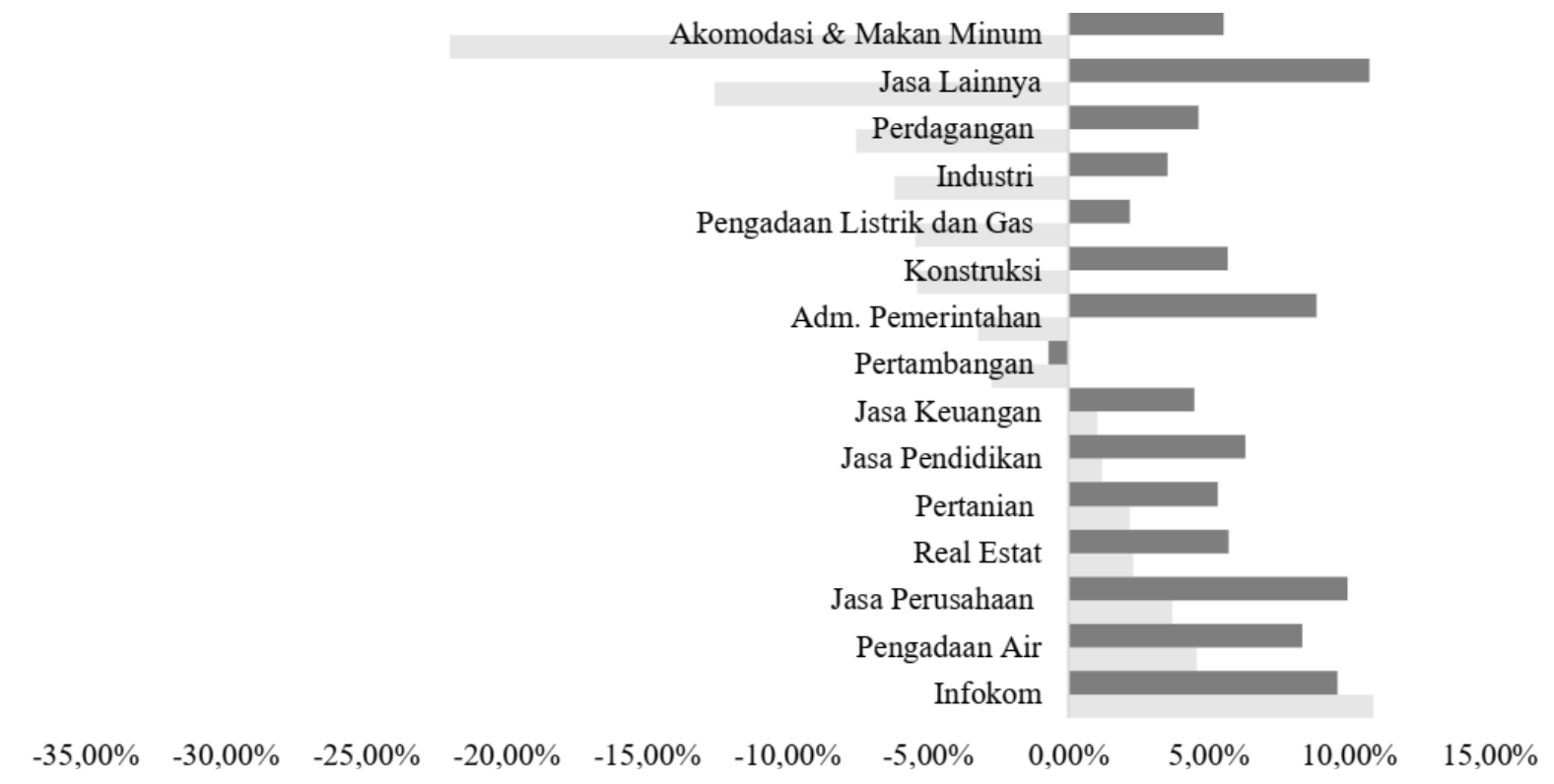

Sumber: Badan Pusat Statistik (2020)

Gambar 4: Struktur pertumbuhan PDB menurut lapangan usaha Triwulan II 2020 (Y-on-Y)

Selain melihat kelompok rentan melalui sektor yang terdampak oleh krisis Covid-19, kerentanan juga terlihat dari seberapa besar konsumsi per kapita yang dilakukan oleh rumah tangga dalam sebulan. Kategorisasi ini akan mengelompokkan masyarakat menjadi kelas-kelas konsumsi yang kemudian juga digunakan untuk mengelompokkan masyarakat miskin dan tidak miskin.

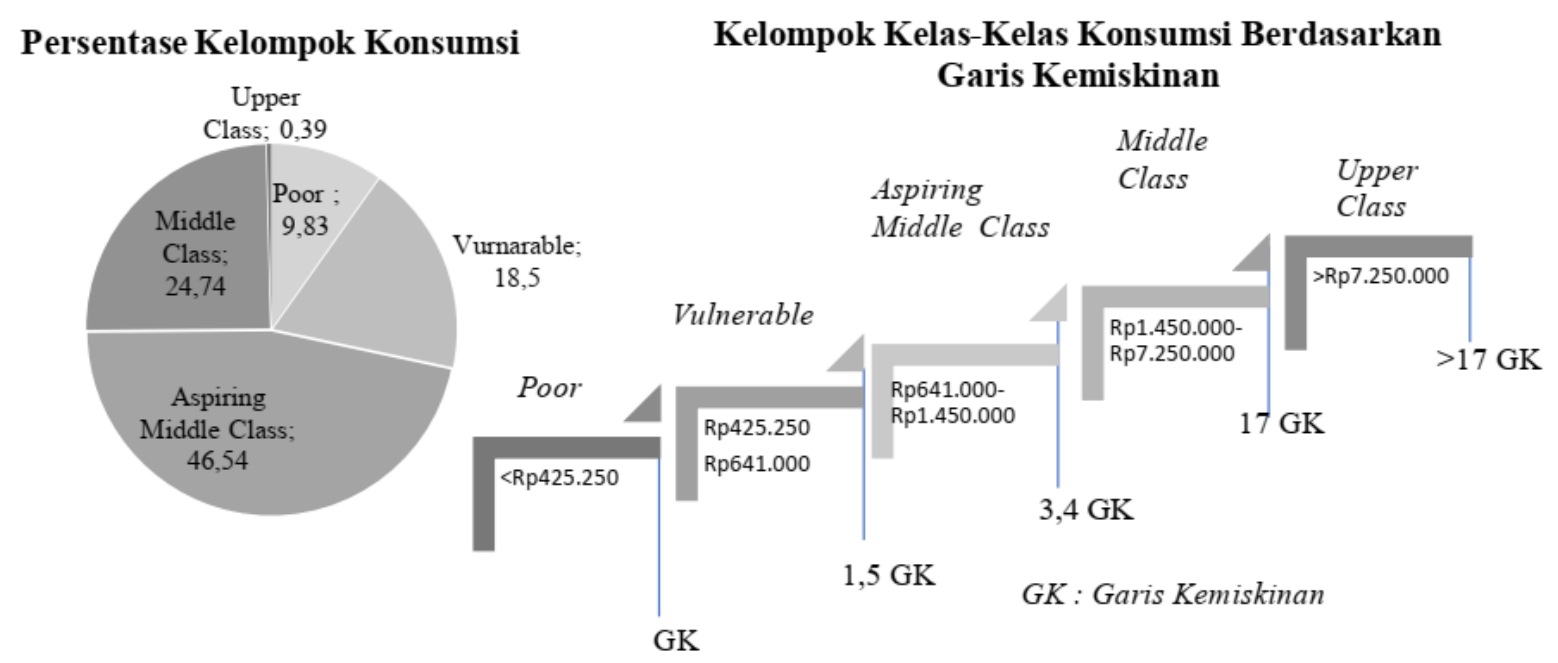

Sumber: Data Susenas 2019, diolah

\section{Gambar 5: Persentase kelompok konsumsi dan pembagian kelas-kelas konsumsi berdasarkan garis kemiskinan}

Berdasarkan garis kemiskinan yang ditetapkan oleh Badan Pusat Statistik (BPS) kelompok miskin adalah mereka dengan pengeluaran per kapita kurang dari Rp425.250/bulan, sementara kelompok rentan memiliki pengeluaran per kapita antara Rp425.250-Rp641.000/ bulan. Berdasarkan data tersebut jumlah penduduk miskin diproyeksikan mencapai 9,83\% (26,24 juta orang), di tahun yang sama jumlah kelompok rentan diproyeksikan mencapai $18,5 \%$ (49,38 juta orang). Dengan jumlah penduduk miskin dan rentang yang cukup besar, pemerintah perlu membuat kebijakan yang tepat agar kelompok miskin tidak jatuh sema- 
kin miskin, kelompok rentan tidak menjadi miskin, dan kelompok kelas kelas menengah tidak turun menjadi kelompok rentan.

\section{Proyeksi dan Estimasi dampak Covid-19 Terhadap Kelompok Miskin dan Rentan}

Sebelum terjadinya krisis Covid-19, krisis kebencanaan lainnya khususnya bencana alam telah memberikan dampak sosial yang tidak sedikit baik pada tingkat kemiskinan, tingkat pengangguran, dan kesenjangan. Dampak negatif dari bencana alam (natural disaster) telah banyak dikonfirmasi oleh berbagai penelitian. Bencana alam (banjir, angin puting beliung, dan kekeringan) berdampak negatif terhadap pendapatan dan pengeluaran rumah tangga (Arouri dkk., 2015). Penelitian lainnya menyebutkan bencana alam (khususnya gempa bumi) berdampak paling besar pada kesejahteraan rumah tangga (Dartanto, 2017). Beberapa penelitian lainnya menunjukkan hasil yang senada (Benson, 1997; De Haen \& Hemrich, 2007; Lindell \& Prater, 2003; Pelling dkk., 2002).

Pada krisis Covid-19 efek yang diberikan lebih luas dibandingkan dengan bencana alam yang sebagian besar hanya berdampak pada wilayah tertentu. Adanya pembatasan (restriction) baik di tingkat daerah maupun nasional telah membuat aktivitas ekonomi terganggu baik pada sistem distribusi logistik, pelayanan masyarakat, hingga pergerakan orang antar wilayah. Kondisi ini tentu berdampak terhadap semua kalangan terutama pada kelompok miskin dan rentan. Sejumlah peneliti pun membuat proyeksi maupun estimasi dampak dari krisis Covid-19 ini terhadap berbagai permasalah sosial. Proyeksi kemiskinan secara global diperkirakan meningkat antara 420-580 juta orang (proyeksi terburuk) dengan prediksi akan terdapat kontraksi pendapatan konsumsi sebesar 20\%. Akan tetapi angka ini bisa lebih rendah dengan skenario yang lebih rendah yakni kontraksi 5\% dan 10\% serta menggunakan garis kemiskinan internasonal US\$1.90, US\$3.20 dan US\$5.50 per hari (Sumner dkk., 2020).

Estimasi global tersebut senada dengan yang terjadi di beberapa wilayah misalnya, lockdown yang terjadi di Sanfransisco membuat kemiskinan meningkat dari 17,1\%-25,9\% pada wilayah teluk yang tidak ada program pengaman sosialnya (social protection) (Martin, 2020). Kemudian penelitian di Filipina menemukan bahwa dengan skenario sedang (medium scenario) krissi Covid-19 berdampak pada penurunan pendapatan sebesar $10 \%$ yang dapat mengakibatkan tambahan 5,5 juta penduduk miskin baru. Namun, angka ini bisa lebih kecil dengan adanya bantuan sosial dari pemerintah, kemiskinan hanya akan bertambah 1,5 juta orang. Poin penting lainnya dalam penelitian ini adalah kelompok tidak miskin juga perlu mendapatkan perhatian. Sebab, kontraksi pada PDB juga membuat kelompok lainnya berkurang pendapatannya. Apabila ini tidak ditangani dengan baik maka kelompok tersebut juga akan turun kelas menjadi kelompok rentan bahkan miskin (Albert dkk., 2020). Berkebalikan dengan penelitian-penelitian sebelumnya, penelitian yang dilakukan oleh Han (2020) menemukan pandemi tidak berdampak pada turunnya pendapatan pada rumah tangga di United States (US), hal ini dikarenakan pemerintah memberikan treatment yang baik di awal-awal masa pandemi agar pandemi tidak berdampak pada pendapatan melalui social safety net program termasuk diantaranya asuransi pengangguran dan bantuan bagi rumah tangga yang terdampak secara ekonomi.

\section{Metodologi Penelitian}

\section{Sumber Data Penelitian}

Penelitian ini menggunakan 2 sumber data sekunder yang diperoleh dari Survei Sosio Ekonomi Nasional (SUSENAS) dan Indonesia Family Life Survey (IFLS). Susenas merupakan survei tahunan yang salah satunya digunakan untuk melihat indikator perubahan kondisi sosio 
ekonomi dari penduduk Indonesia dari tahun ke tahun. Survei ini juga digunakan oleh pemerintah untuk melihat tingkat kemiskinan serta distribusi kesejahteraan dari penduduk Indonesia. Penelitian ini menggunakan data yang disediakan oleh Susenas sebagai sumber data utama dengan tambahan dukungan data dari IFLS. Sebagai sumber utama, data dari susenas akan digunakan untuk mengkonstruksi sebagian besar variabel penelitian seperti status ekonomi, status pekerjaan, bantuan pemerintah, dll. Keterbatasan variabel yang termuat di dalam Susenas membuat penelitian ini menggunakan dukungan data dari IFLS untuk variabel indikator kesejahteraan seperti nilai aset, tabungan, dan pendapatan. Walaupun demikian, data IFLS terbaru hanya bisa didapatkan pada tahun 2014 sehingga ini menjadi salah satu keterbatasan penelitian ini karena menggunakan sumber data di titik waktu yang berbeda. Sama seperti Susenas, IFLS merupakan survei yang mencakup keadaan sosio ekonomi dan kesehatan dari penduduk Indonesia. Sampel dari IFLS merepresentasikan 83\% populasi penduduk Indonesia yang tinggal di 13 provinsi dari 26 provinsi pada tahun 1993 (Strauss dkk., 2016). Secara keseluruhan, ada 5 gelombang survei yang tercakup dalam IFLS yaitu dari gelombang 1 pada tahun 1993 hingga gelombang 5 pada tahun 2014.

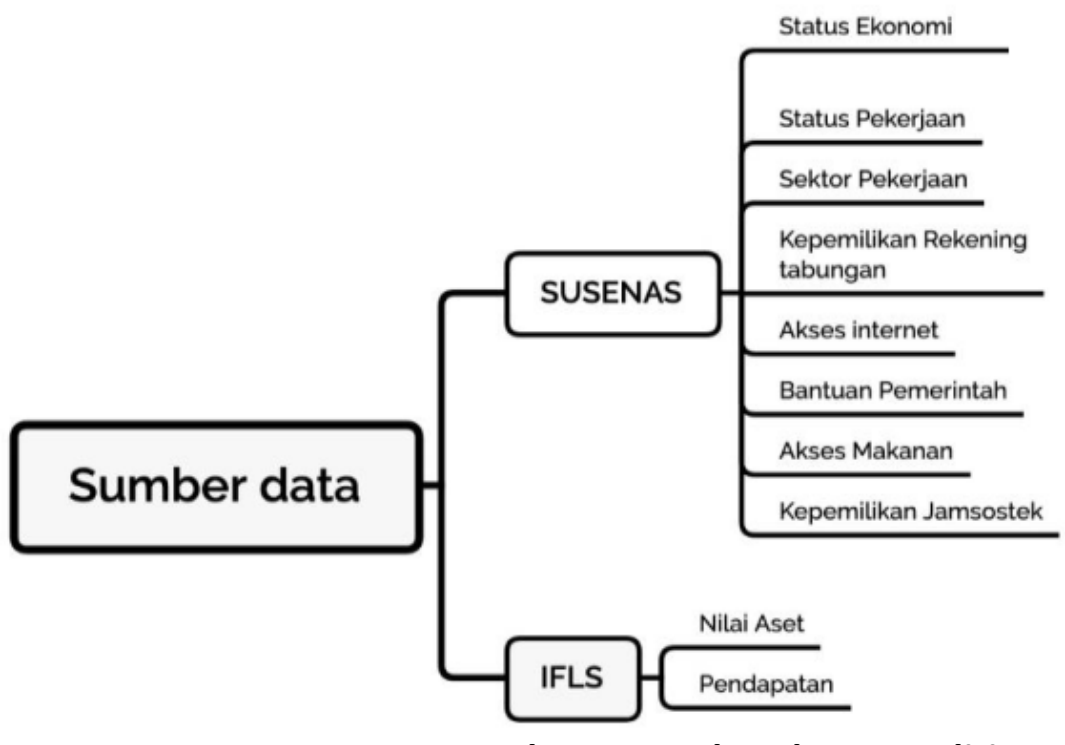

Gambar 6: Sumber data penelitian

\section{Kerangka Analisis}

Sampel yang digunakan dibatasi pada individu yang aktivitas utamanya adalah bekerja dengan umur di atas 15 tahun. Individu yang bekerja ini juga dibatasi dengan mengeluarkan individu yang bekerja sebagai pekerja bebas dan pekerja tidak dibayar. Penelitian ini akan berfokus untuk menganalisis berbagai karakteristik yang berpengaruh terhadap resiliensi ekonomi individu yang dilihat dari 2 dimensi yaitu dimensi status ekonomi dan status pekerjaan dengan menggunakan metode analisis kuantitaif deskriptif. Metode ini memungkinkan untuk dilakukan analisis multidimensi sehingga didapatkan informasi yang lebih mendalam terkait karakteristik individu yang menjadi kriteria reseilensi ekonomi. Kerangka analisis di dalam penelitian ini mengacu pada teori yang dikemukakan FAO (2009) yang menjelaskan beberapa kondisi atau kriteria yang berpengaruh terhadap resiliensi ekonomi. Dari teori tersebut, penelitian ini menggunakan variabel yang ada untuk dijadikan sebagai proxy yang dapat mencerminkan beberapa kriteria tersebut. Gambar menggambarkan kerangka analisis yang digunakan di dalam penelitian ini. 


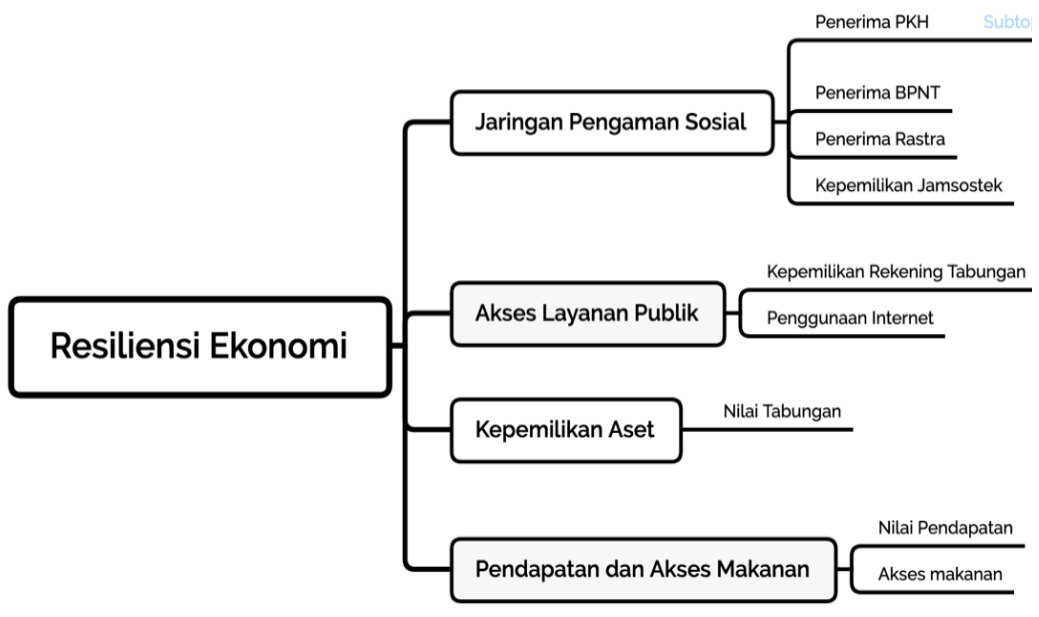

Gambar 7: Badan Indikator Resiliensi Ekonomi Rumah Tangga

\section{Hasil dan Pembahasan}

\section{Statistik Deskriptif}

Tabel 3: Statistik deskriptif karakteristik sampel penelitian secara umumn (dalam \%)

\begin{tabular}{|c|c|c|c|c|c|}
\hline Variabel & Jumlah & Persentase & Variabel & Jumlah & Persentase \\
\hline \multicolumn{3}{|l|}{ Status Ekonomi } & \multicolumn{3}{|l|}{ Wilayah } \\
\hline Miskin & 4.901 & $10,81 \%$ & Kota & 21.155 & $55,88 \%$ \\
\hline Rentan & 8.044 & $21,25 \%$ & Desa & 16.703 & $44,12 \%$ \\
\hline Calon kelas menengah & 17.561 & $46,39 \%$ & \multicolumn{3}{|l|}{ Sektor Pekerjaan } \\
\hline Kelas menengah & 8.403 & $21,25 \%$ & Pertanian & 9.915 & $26,19 \%$ \\
\hline Kelas atas & 119 & $0,31 \%$ & Manufaktur & 5.924 & $15,65 \%$ \\
\hline \multicolumn{3}{|l|}{ Status Pekerjaan } & Perdagangan & 7.295 & $19,27 \%$ \\
\hline Pelaku usaha & 19091 & $50,43 \%$ & Jasa & 12.458 & $32,91 \%$ \\
\hline Pekerja & 18767 & $49,57 \%$ & Sektor lain & 2.266 & $5,99 \%$ \\
\hline \multicolumn{3}{|l|}{ Pendidikan } & \multicolumn{3}{|l|}{ Penggunaan internet } \\
\hline Tidak berpendidikan & 1.941 & $5,13 \%$ & Menggunakan & 19.356 & $51,13 \%$ \\
\hline Pendidikan primer & 21.248 & $56,13 \%$ & Tidak menggunakan & 18.502 & $48,87 \%$ \\
\hline Pendidikan sekunder & 9.686 & $25,59 \%$ & \multicolumn{3}{|c|}{ Penggunaan internet untuk Jual Beli } \\
\hline Pendidikan tinggi & 4.983 & $13,16 \%$ & Menggunakan & 3.752 & $9,91 \%$ \\
\hline \multicolumn{3}{|c|}{ Kepemilikan Rekening Tabungan } & Tidak menggunakan & 34.106 & $90,09 \%$ \\
\hline Memiliki & 16.734 & $44,2 \%$ & \multicolumn{3}{|l|}{ Kepemilikan Jamsostek } \\
\hline Tidak memiliki & 21.124 & $55,8 \%$ & Memiliki & 3.890 & $10,28 \%$ \\
\hline \multicolumn{3}{|l|}{ Penerima Bantuan } & Tidak memiliki & 33.968 & $89,72 \%$ \\
\hline Penerima PKH & 4.753 & $12,55 \%$ & & & \\
\hline Penerima BPNT & 5.605 & $14,81 \%$ & & & \\
\hline Penerima RASTRA & 2.203 & $5,82 \%$ & & & \\
\hline Total Observasi & & & 37.858 & & \\
\hline
\end{tabular}

Sebelum melakukan analisis multidimensi, bagian ini akan menunjukkan gambaran terkait karakteristik masyarakat Jawa Timur secara umum dari berbagai karakteristik yang ditunjukkan pada tabel 3 di atas. Perlu digarisbawahi bahwa penelitian ini menggunakan sampel 
hanya pada individu yang bekerja. Total sampel individu dari kelompok tenaga kerja berjumlah 37.858. Dari jumlah tersebut, 55,88\% tinggal di daerah perkotaan dan sisanya tinggal di pedesaan. Hal ini mengindikasikan bahwa sebagian besar masyarakat Jawa Timur merupakan masyarakat perkotaan. Berdasarkan status ekonomi, kelompok calon menengah memiliki proporsi yang paling besar $(46,39 \%)$ dan kemudian diikuti oleh kelompok rentan dan kelompok menengah dengan proporsi yang sama $(21,25 \%)$. Sedangkan, kelompok miskin di Jawa Timur dari golongan pekerja memiliki persentase sebesar 10,81\%.

Jika dilihat dari status pekerjaan, pelaku usaha dan pekerja memiliki proporsi yang relatif sama sehingga komparasi berdasarkan status pekerjaan pada penelitian ini ideal untuk dilakukan. Sebagian besar kelompok tenaga kerja di Jawa timur memiliki pendidikan di tingkat primer dengan proporsi sebesar $56,13 \%$ dan diikuti oleh kelompok dengan pendidikan sekunder dan tinggi dengan masing-masing sebesar $25,59 \%$ dan $13,16 \%$. Sektor pekerjaan yang paling diminati oleh masyarakat Jawa Timur adalah sektor jasa dengan proporsi sebesar $32,91 \%$, diikuti dengan pertanian $(26,19 \%)$, perdagangan $(19,27 \%)$, dan manufaktur $(15,65 \%)$.

\section{Analisis Kelompok Rentan Pada Rumah Tangga di Jawa Timur}

Pada bagian ini akan memaparkan hasil temuan mengenai kondisi rumah tangga di Jawa Timur berdasarkan 4 aspek untuk mengukur resiliensi rumah tangga. Empat aspek tersebut diantaranya adalah jaring pengamanan sosial, akses pada layanan publik, kepemilikan aset, serta pendapatan dan akses pangan (FAO, 2009). Untuk memperkaya analisis peneliti menambahkan aspek sektor pekerjaan untuk melihat kerentanan rumah tangga pada setiap sektor dikaitkan dengan kontraksi ekonomi pada triwulan II 2020 kemarin yang membuat sebagian besar sektor lapangan usaha mengalami tekanan berat.

\section{Sektor Pekerjaan}

Tabel 4: Proporsi kelas konsumsi rumah tangga berdasarkan sektor pekerjaan (dalam \%)

\begin{tabular}{llllll}
\hline \multicolumn{1}{c}{ Umum } & P & V & AMC & MC & UC \\
\hline Pertanian & 50,4 & 35,6 & 24 & 9,5 & 7,6 \\
\hline Manufaktur & 12,1 & 14,3 & 17,2 & 15,6 & 13,4 \\
\hline Perdagangan & 13,7 & 17,4 & 20,7 & 20,8 & 19,3 \\
\hline Jasa & 18,3 & 25,5 & 32 & 49,4 & 56,3 \\
\hline Sektor lain & 5,5 & 7,1 & 6,2 & 4,7 & 8,4 \\
\hline \multicolumn{1}{c}{ Pelaku Usaha } & & & & & \\
\hline Pertanian & 65,2 & 50,7 & 39,7 & 20,2 & 17,6 \\
\hline Manufaktur & 6,9 & 7,1 & 8,2 & 9,2 & 2 \\
\hline Perdagangan & 14,9 & 20,6 & 27,8 & 37,5 & 43,1 \\
\hline Jasa & 11,5 & 19,7 & 22,4 & 30,2 & 27,5 \\
\hline Sektor lain & 1,5 & 1,9 & 2 & 9,8 & 2,8 \\
\hline \multicolumn{1}{c}{ Pekerja } & & & & & \\
\hline Pertanian & 24,2 & 16,2 & 8,4 & 2,7 & 0 \\
\hline Manufaktur & 21,3 & 23,6 & 26,1 & 19,7 & 13,2 \\
\hline Perdagangan & 11,6 & 13,3 & 13,7 & 10,2 & 1,5 \\
\hline Jasa & 30,4 & 33 & 41,6 & 61,6 & 77,92 \\
\hline Sektor lain & 12,6 & 13,9 & 10,3 & 5,9 & 7,4 \\
\hline
\end{tabular}


Pada bagian ini akan dijelaskan mengenai analisis sektoral berdasarkan status ekonomi dan pekerjaan dari masing-masing individu. Dari tabel 4 dapat dilihat bahwa untuk kelompok miskin, sebagian besar bekerja pada sektor pertanian $(50,4 \%)$. Namun jika dilihat dari status pekerjaan, ada perbedaan antara mereka yang bekerja sebagai pelaku usaha dan pekerja. Untuk pelaku usaha, sebagian besar kelompok miskin bekerja pada sektor pertanian $(65,2 \%)$, sedangkan sektor jasa $(30,4 \%)$ menjadi sektor dominan untuk pekerja yang berada pada kelompok miskin. Pola serupa juga dapat ditemukan untuk kelompok rentan dimana secara umum, sebagian besar kelompok rentan berada pada sektor pertanian (35,6\%). Pelaku usaha yang masuk pada golongan rentan sebagian besar bekerja pada sektor pertanian (50,7\%), sedangkan pekerja pada kelompok rentan sebagian besar berada pada sektor jasa (30,4\%). Dari hasil dapat diambil beberapa poin. Pertama, mayoritas kelompok miskin dan rentan bekerja pada sektor pertanian. Namun hal ini tidak berlaku jika dilihat berdasarkan status pekerjaan dimana pelaku usaha yang miskin dan rentan lebih banyak bekerja pada sektor pertanian, sedangkan pekerja lebih banyak pada sektor jasa.

\section{Sektor Jaring Pengaman Sosial}

\section{Tabel 5: Proporsi kelas konsumsi rumah tangga berdasarkan penerimaan jaring pengaman} sosial (dalam \%)

\begin{tabular}{|c|c|c|c|c|c|}
\hline Jaring Pengaman Sosial & $\mathbf{P}$ & $\mathbf{V}$ & AMC & MC & UC \\
\hline \multicolumn{6}{|l|}{ Umum } \\
\hline Penerima PKH & 26,6 & 20 & 10,9 & 1,8 & 0 \\
\hline Penerima BPNT & 13,5 & 6,8 & 4,9 & 1,3 & 0 \\
\hline Penerima RASTRA & 25,8 & 23,2 & 14 & 2,8 & 1,7 \\
\hline Kepemilikan Jamsostek & 1,5 & 3,7 & 8,9 & 24 & 26,1 \\
\hline \multicolumn{6}{|l|}{ Kepemilikan JKN } \\
\hline \multicolumn{6}{|l|}{ Pelaku Usaha } \\
\hline Penerima PKH & 26 & 19,1 & 10,9 & 2,4 & 0 \\
\hline Penerima BPNT & 25,8 & 21,7 & 13,6 & 3,9 & 3,7 \\
\hline Penerima RASTRA & 17,1 & 8,9 & 7,5 & 2,2 & 0 \\
\hline Kepemilikan Jamsostek & 0,9 & 2,4 & 13,1 & 30,8 & 36,8 \\
\hline \multicolumn{6}{|l|}{ Kepemilikan JKN } \\
\hline \multicolumn{6}{|l|}{ Pekerja } \\
\hline Penerima PKH & 27,9 & 21 & 10,9 & 1,4 & 0 \\
\hline Penerima BPNT & 25,8 & 25,2 & 14,3 & 2,2 & 0 \\
\hline Penerima RASTRA & 12 & 4,7 & 2,8 & 0,8 & 0 \\
\hline Kepemilikan Jamsostek & 2,7 & 5,4 & 4,8 & 11,8 & 13,4 \\
\hline Kepemilikan JKN & & & & & \\
\hline
\end{tabular}

Bagian ini akan menganilisis aspek jaring pengaman sosial yang diterima oleh kelompok tenaga kerja di Jawa Timur berdasarkan status ekonomi dari masing-masing individu. Ada 5 kriteria yang digunakan untuk mencerminkan aspek jaring pengaman sosial yaitu proporsi penerima Program Keluarga Harapan (PKH), Beras Strategis (Rastra), Bantuan Pangan Non Tunai (BPNT) dan pemilik Jaminan Sosial Tenaga Kerja (Jamsostek). Analisis ini bertujuan untuk mengidentifikasi apakah bantuan yang selama ini diberikan oleh pemerintah telah tepat menyasar kelompok yang paling membutuhkan bantuan tersebut. Dari analisis deskriptif sebelumnya, bantuan yang paling banyak diterima oleh kelompok tenaga kerja di Jawa Timur ada- 
lah BPNT (14,81\%) dan diikuti oleh PKH (12,55\%), dan Rastra (5,82\%). Tabel 5 menunjukkan gambaran dari penerima program tersebut berdasarkan status ekonomi dan status pekerjaan. Secara umum, kelompok miskin dan rentan merupakah kelompok dengan proporsi penerima bantuan yang paling besar dibandingkan kelompok lainnya. Misalnya untuk program PKH, proporsi kelompok miskin dan rentan yang menerima bantuan masing-masing sebesar $26,6 \%$ dan $20 \%$. Hal serupa juga berlaku untuk penerima program BPNT dan Rastra. Namun dari tabel tersebut, jika dilihat lebih jauh, proporsi kelompok rentan dan miskin yang menerima 3 bantuan tersebut di bawah angka 30\%. Hal ini mengindikasikan bahwa ada lebih dari $70 \%$ dari kelompok rentan dan miskin di Jawa Timur yang belum mendapatkan kesempatan untuk menerima program tersebut. Jika dilakukan analisis parsial berdasarkan status pekerjaan, tidak ada perbedaan signifikan dari proporsi penerima bantuan baik untuk pekerja maupun pelaku usaha. Proporsi penerima bantuan yang ada di kedua kelompok tersebut juga masih di bawah $30 \%$.

Hal lain yang perlu dicermati adalah bahwa bantuan yang diberikan oleh pemerintah ini masih menyasar kelompok calon menengah dan menengah. Hal ini berarti bahwa sasaran dari program bantuan yang diberikan oleh pemerintah cenderung tidak tepat sasaran. Kepemilikan jamsostek menunjukkan pola yang terbalik jika dibandingkan dengan penerima bantuan dimana semakin rendah golongan ekonomi individu, semakin kecil proporsi yang memiliki Jamsostek. Secara umum, kepemilikan jamsostek dari kelompok miskin dan rentang berada di bawah 5\%. Namun jika dilihat berdasarkan status pekerjaan, proporsi kelompok pekerja $(5,4 \%)$ yang memiliki jamsostek lebih tinggi dibandingkan kelompok pelaku usaha $(2,7 \%)$.

\section{Sektor Akses Layanan Publik}

Tabel 6: Proporsi kelas konsumsi rumah tangga berdasarkan akses pada layanan publik (dalam \%)

\begin{tabular}{|c|c|c|c|c|c|}
\hline Sektor & $\mathbf{P}$ & V & AMC & MC & UC \\
\hline \multicolumn{6}{|l|}{ Umum } \\
\hline Penggunaan Internet & 24,6 & 35,6 & 51,9 & 77,9 & 86,6 \\
\hline Penggunaan Internet untuk jual beli & 2 & 4,2 & 8,5 & 22,3 & 36,1 \\
\hline Kepemilikan Rekening tabungan & 20 & 28,2 & 43,4 & 73,7 & 79 \\
\hline \multicolumn{6}{|l|}{ Pelaku Usaha } \\
\hline Penggunaan Internet & 13 & 21,4 & 33 & 59 & 74,5 \\
\hline Penggunaan Internet untuk jual beli & 1,4 & 3,4 & 7,1 & 19,9 & 43,1 \\
\hline Kepemilikan Rekening tabungan & 16,4 & 23,3 & 34,3 & 60,9 & 88,2 \\
\hline \multicolumn{6}{|l|}{ Pekerja } \\
\hline Penggunaan Internet & 45,3 & 54 & 70,7 & 89,9 & 95,6 \\
\hline Penggunaan Internet untuk jual beli & 3,1 & 5,3 & 9,9 & 23,8 & 30,9 \\
\hline Kepemilikan Rekening tabungan & 26,6 & 34,5 & 52,6 & 72,1 & 81,8 \\
\hline
\end{tabular}

Sektor akses layanan publik diwakilkan oleh variabel penggunaan internet dan kepemilikan buku rekening tabungan. Penggunaan internet pada kelompok miskin dan rentan relatif kecil dibandingkan dengan kelas di atasnya. Hanya $24,6 \%$ kelompok miskin yang mempunyai akses pada internet dan hanya 35,6\% pada kelompok rentan. Kemudian angka ini semakin kecil ketika dispesifikkan ke penggunaan internet untuk media jual beli. Secara umum hanya $2 \%$ kelompok miskin dan 4,2\% kelompok rentan yang menggunakan intenet untuk keperluan jual beli. Penggunaan internet oleh Pekerja lebih tinggi dibandingkan dengan pelaku usaha yakni 
sebesar 45,3\%. Kemudian penggunaan internet untuk keperluan jual beli juga lebih tinggi oleh Pekerja $(3,1 \%)$ dibandingkan dengan pelaku usaha $(1,4 \%)$.

Pada variabel kepemilikan rekening tabungan di lembaga keuangan secara umum juga rendah pada kelompok miskin (20\%\%) dan rentan $(28,2 \%)$. Kepemilikan rekening tabungan lebih tinggi oleh Pekerja yang terkategori miskin dan rentan dibandingkan dengan pelaku usaha. Kelompok miskin dan rentan pada sampel Pekerja memiliki rekening masing-masing $26,6 \%$ dan $34,5 \%$. Angka ini terlampau jauh dibandingkan dengan pelaku usaha miskin dan rentan yang masing-masing hanya memiliki $16,4 \%$ dan $23,3 \%$. Dari temuan ini terlihat bahwa kelompok miskin dan rentan memiliki tingkat resiliensi yang lebih rendah dibandingkan dengan kelompok lainnya dikarenakan sistem pertahanan diri yang rendah. Kepemilikan rekening adalah satu jalur untuk mendapatkan bantuan pemerintah dan akses internet yang memadai sangat bermanfaat untuk bisa berjualan di marketplace atau jual beli online konvensional lainnya di tengah pembatasan saat ini terutama bagi pelaku usaha. Apabila dua indikator ini tidak dimiliki maka akan mempengaruhi tingkat resiliensi rumah tangga tersebut.

Tabel 7: Korelasi antara status kemiskinan, penggunaan internet, dan kepemilikan tabungan

\begin{tabular}{|c|c|c|c|c|}
\hline Variabel & Status Kemiskinan & $\begin{array}{l}\text { Penggunaan } \\
\text { Internet }\end{array}$ & $\begin{array}{l}\text { Penggunaan } \\
\text { Internet untuk } \\
\text { Jual Beli }\end{array}$ & $\begin{array}{c}\text { Kepemilikan } \\
\text { Tabungan }\end{array}$ \\
\hline $\begin{array}{l}\text { Status Kemi- } \\
\text { skinan }\end{array}$ & 1 & & & \\
\hline $\begin{array}{l}\text { Penggunaan } \\
\text { Internet }\end{array}$ & $-0,1820 *$ & 1 & & \\
\hline $\begin{array}{l}\text { Penggunaan } \\
\text { Internet untuk } \\
\text { Jual Beli }\end{array}$ & $-0,0935^{*}$ & $0,3252^{*}$ & 1 & \\
\hline $\begin{array}{l}\text { Kepemilikan } \\
\text { Tabungan }\end{array}$ & $-0,1652 *$ & $0,4329 *$ & $0,2579 *$ & 1 \\
\hline
\end{tabular}

Keterangan: *menunjukkan tingkat signifikansi dalam $5 \%$

Tabel di atas menunjukkan hubungan (correlation) antara status kemiskinan, penggunaan internet, dan kepemilikan tabungan. Secara rata-rata terdapat hubungan negatif antara akses terhadap layanan publik (internet dan akses layanan perbankan) terhadap status kemiskinan seseorang. Orang-orang dengan kepemilikan tabungan atau akses internet lebih cenderung berstatus tidak miskin dibandingkan dengan orang-orang yang tidak mempunyai akses terhadap kedua hal tersebut. Selain itu, diantara kepemilikan tabungan dan akes internet, penggunaan akses internet secara umum mempunyai hubungan paling tinggi dengan status kemiskinan dibandingkan dengan yang lainnya.

Adapun hal lain yang dapat dilihat adalah hubungan antara akses internet secara umum, akses internet untuk jual beli, dan kepemilikan tabungan adalah positif. Hal ini berarti, akses terhadap satu layanan publik juga meningkatkan peluang seseorang untuk mempunyai akses terhadap layanan publik lainnya. Sebagai contoh, orang-orang yang memiliki tabungan perbankan berpeluang mengakses internet secara umum sebesar $43,29 \%$ dan akses internet untuk jual beli sebesar $25,79 \%$, dan sebaliknya. Hasil ini penting untuk ditelaah lebih lanjut terutama untuk membuat kebijakan di tingkat daerah khusus Jawa Timur bahwa peningkatan pada akses layanan publik dalam hal ini akses internet dan perbankan dapat menambah kesejahteraan. 
Sektor Akses Pangan, Pendapatan, dan Kepemilikan Aset

Tabel 8: Proporsi kelas konsumsi rumah tangga berdasarkan akses pangan (dalam \%)

\begin{tabular}{lccccr}
\hline Akses Pangan & P & V & AMC & MC & UP \\
\hline Umum & & & & & \\
\hline Kesulitan Akses Pangan & 10,7 & 6,7 & 3,9 & 1,1 & 0 \\
\hline Pelaku Usaha & & & & & \\
\hline Kesulitan Akses Pangan & 10,3 & 6,2 & 3,7 & 0,9 & 0 \\
\hline Pekerja & & & & & \\
\hline Kesulitan Akses Pangan & 11,4 & 7,2 & 4,1 & 1,2 & 0 \\
\hline
\end{tabular}

Tabel 9: Proporsi kelas konsumsi rumah tangga berdasarkan pendapatan dan kepemilikan aset (dalam rupiah)

\begin{tabular}{lccccc}
\hline Pendapatan dan Aset & P & V & AMC & MC & UP \\
\hline Umum & & & & & \\
\hline Pendapatan (rata-rata) & Rp22.900.000 & Rp27.100.000 & Rp35.000.000 & Rp62.600.000 & Rp94.800.000 \\
\hline Aset (rata-rata) & Rp87.300.000 & Rp112.000.000 & Rp151.000.000 & Rp304.000.000 & Rp460.000.000 \\
\hline
\end{tabular}

Bagian ini akan menjelaskan kondisi rumah tangga di jawa timur dalam mengakses pangan, kepemilikan pendapatan, dan kepemilikan aset. Data mamaparkan bahwa secara umum masalah akses pangan masih cukup menghawatirkan sebab secara umum masih terdapat $10,7 \%$ penduduk miskin yang kesulitan mengakses pangan, pada kelompok rentan terdapat 6,7\% yang kesulitan mengakses pangan, bahkan pada kelas menengah pun masih terdapat yang kesulitan mengakses pangan (1,1\%). Kemudian observasi pelaku usaha lebih mempunyai ketahanan dibandingkan dengan obersevasi Pekerja. Sebanyak $10,3 \%$ pelaku usaha masih merasakan kesulitan mengakses pangan, sementara angka yang lebih tinggi ditunjukkan oleh Pekerja yakni 11,4\%.

Dalam hal kepemilikan pendapatan dan kepemilikan aset sudah tentu kelompok miskin dan rentan relatif memiliki pendapatan dan kepemilikan aset yang lebih sedikit dibandingkan dengan kelas-kelas di atasnya. Pendapatan rata-rata setahun kelompok miskin sebesar 22,9 juta rupiah dan kelompok rentan sebesar 27,1 juta rupiah. Sementara kelompok calon kelas menengah (Rp35 juta), kelas menengah (Rp62,6 juta), dan kelas atas (Rp94,8 juta) memiliki pendapatan rata-rata yang lebih tinggi. Data kelompok miskin dan rentan juga tidak jauh dengan pendapatan. Rata-rata kepemilikan aset rumah tangga miskin dan rentan masing sebesar Rp87,3 juta dan Rp112 juta. Sementara calon kelas menengah, kelas menengah, dan kelas atas masing-masing memiliki aset sebesar Rp151 juta, Rp304 juta, dan Rp460 juta. Kedua indikator menunjukkan bahwa kelompok miskin dan rentan memiliki tingkat resiliensi yang rendah relatif terhadap kelompok lainnya apabila terjadi shock (goncangan) pada perekonomian mereka. Dengan pendapatan yang kecil dan kepemilikan aset yang sedikit dapat dengan mudah membuat kelompok miskin menjadi semakin miskin dan kelompok rentan turun menjadi miskin jika tidak terdapat jaring pengaman sosial yang memadai.

\section{Relevansi Hasil Temuan dengan Kebijakan yang Ada}

1. Sektor Pekerjaan: Sebagian besar kelompok miskin dan rentan bekerja di sektor pertanian. Walaupun temuan ini berbeda pada observasi pelaku usaha dan pekerja. Pelaku usaha yang miskin dan rentan sebagian besar bekerja di sektor pertanian, sementara pekerja miskin dan rentan bekerja di sektor jasa. Namun, program-program yang diim- 
plementasikan pemerintah baik pusat maupun daerah belum ada yang menargetkan secara sektoral. Padahal dampak Covid-19 pada setiap sektor berbeda-beda seperti yang ditunjukkan pada laporan PDB Triwulan II 2020.

2. Program Jaring Pengaman Sosial : masih terdapat exclusion error dan inclusion error yang mana hanya sekitar $30 \%$ dari kelas miskin dan rentan yang menerima program jaring pengaman sosial (PKH, BPNT, Rastra). Sementara terdapat calon kelas menengah dan kelas menengah yang masih menerima program jaring pengaman tersebut. Temuan lainnya adalah masih sedikit yakni di bawah 5\% kelompok tenaga kerja yang miskin dan rentan yang memiliki jamsostek. Sementara salah satu program pemerintah adalah bantuan langsung tunai kepada tenaga kerja dengan gaji di bawah 5 juta rupiah dan memiliki jamsostek. Artinya program tersebut tidak banyak menjangkau tenaga kerja yang miskin dan rentan.

3. Akses Layanan Publik: Salah satu program pemerintah adalah kartu prakerja yang mana program tersebut mengharuskan calon penerimanya untuk dapat mengakses internet. Temuan di lapangan menyebutkan bahwa kelompok miskin dan rentan sebagian besar tidak dapat mengakses internet yakni hanya 24,6\% (miskin) dan 35,6\% (rentan). Artinya program kartu prakerja ini kurang inklusif dan menyasar kelompok tertentuk khususnya kelas menengah ke atas. Lebih jauh lagi, penggunaan internet untuk keperluan jual beli sangat kecil pada kelompok miskin dan rentan. Sementara fasilitas tersebut dapat digunakan sebagai altenatif bertahan di tengah pandemi dengan berbagai keterbatasan aktivitas di luar rumah khususnya bagi pelaku usaha. Temuan di lapangan menyebutkan hanya $1,4 \%$ pelaku usaha yang mengakses internet utnuk keperluan jual beli. Untuk variabel kepemilikan rekening sangat berkaitan dengan program pemerintah yakni restrukturisasi kredit. Dengan sedikitnya proporsi kelompok miskin dan rentan yang memiliki rekening tabungan di lembaga keuangan formal maka program ini tidak akan banyak menjangkau kelompok miskin dan rentan di Jawa Timur.

4. Akses pangan, kepemilikan pendapatan, dan kepemilikan akses: Temuan di lapangan memaparkan bahwa masih terdapat $10 \%$ lebih kelompok miskin dan 6,7\% kelompok rentan yang kesulitan mengakses pangan. Hal ini berkaitan dengan salah satu program pemerintah yakni Rastra dan BPNT yang barang harus diperluas jangkauannya sehingga dapat menjangkau seluruh kelompok miskin dan rentan. Temuan lainnya adalah kepemilikan pendapatan dan aset pada kelompok miskin dan rentan relatif jauh lebih kecil dibandingkan dengan kelas-kelas di atasnya. Kondisi ini perlu menjadi perhatian pemerintah dikarenakan kelompok miskin dan rentan tidak cukup punya resiliensi yang kuat di tengah pandemi dengan sumber daya yang terbatas.

\section{Kesimpulan dan Rekomendasi}

\section{Kesimpulan}

Berdasarkan hasil dan pembahasan di atas maka kesimpulan dari penelitian ini adalah tingkat resiliensi dari kelompok miskin dan rentan dalam menghadapi pandemi Covid-19 relatif rendah. Hal ini tercermin dari temuan penelitian ini yang menunjukkan bahwa terdapat kesenjangan antara data di lapangan dan program-progam yang diimplementasikan oleh pemerintah pusat dan daerah. Indikator jaring pengaman sosial yang masih terdapat exclusion dan inclusion error, program yang belum mempertimbangkan isu sektoral, akses terhadap layanan publik yang terbatas, serta mekanisme pertahanan diri yang rendah (pendapatan dan aset) membuat kelompok miskin dan rentan di Jawa Timur menjadi faktor yang mendorong turunnya tingkat resiliensi. 


\section{Rekomendasi}

Berdasarkan kesimpulan di atas maka rekomendasi dalam penelitian ini sebagai berikut :

1. Memperluas jangkauan program-program jaring pengaman sosial yang selama ini sudah diimplementasikan.

2. Memperbaiki pendataan kelompok miskin dan rentan untuk meningkatkan akurasi program

3. Mempertimbangkan isu sektoral pada kebijakan yang diimplementasikan sehingga mampu menjangkau kelompok yang paling membutuhkan/terdampak

4. Memperluas akses layananan keuangan bagi kelompok miskin dan rentan melalui program jemput bola atau pembuatan rekening secara langsung.

5. Menambah jalur akses terhadap program yang diimplementasikan agar dapat dinikmati lebih banyak penduduk dengan berbagai perbedaan keterbatasan. Misalnya pada program kartu prakerja seharusnya tidak hanya menyediakan pintu pendaftaran melalui online saja tetapi juga membuka alternatif pendapatan offline seperti, pendaftaran langsung ke perangkat desa atau dinas terkait.

\section{Daftar Pustaka}

Albert, J. R. G., Abrigo, M. R. M., Quimba, F. M. A., \& Vizmanos, J. F. V. (n.d.). Poverty, the Middle Class, and Income Distribution amid COVID-19. 58.

Arouri, M., Nguyen, C., \& Youssef, A. B. (2015). Natural disasters, household welfare, and resilience: Evidence from rural vietnam. World Development, 70, 59-77.

Badan Pusat Statistik. (2020). Pertumbuhan Ekonomi Indonesia Triwulan IV-2019. Www. Bps.Go.ld, (17/02/Th. XXIV), 1-12. Retrieved from https://www.bps.go.id/pressrelease/2020/02/05/1755/ekonomi-indonesia-2019-tumbuh-5-02-persen.html

Benson, C. (1997). The economic impact of natural disasters in Viet Nam. Working Paper 98, Portland House, Stag Place, London: Overseas Development Institute.

Biro Humas Jatimprov.go.id. (2020, September 21). Percepat Pemulihan Ekonomi, Gubernur Khofifah Kucurkan Bantuan 23,725 Milyar Untuk Pemberdayaan Usaha Perempuan dan 5 Milyar Untuk BUMDES.

Dartanto, T. (2017). Disaster, mitigation and household welfare in Indonesia,. LPEM, Faculty of Economics and Business, University of Indonesia (No. 201706).

De Haen, H., \& Hemrich, G. (2007). The economics of natural disasters: Implications and challenges for food security. Agricultural Economics, 37(1), 31-45.

Dercon, S. (2001). Assessing vulnerability to poverty. Report prepared for the Department for International Development (DFID). Available at: www.economics.ox.ac.uk/members/ stefan.dercon/assessingvulnerability.

FAO. (2009). Measuring Household Relisience to Food Insecurity. Foodsec.Org. Retrieved from http://www.foodsec.org/fileadmin/user_upload/eufao-fsi4dm/docs/resilience_ wp.pdf\%5Cnpapers3://publication/uuid/484EA881-EC20-47DC-89B4-4D5E4926429E

Folke, C. (2006). Resilience: the emergence of a perspective for social-ecological systems analyses. Global Environmental Environmental Change, 16(3): 253-267.

Han, J., Meyer, B. D., \& Sullivan, J. X. (2020). Income and Poverty in the COVID-19 Pandemic 
(No. w27729). National Bureau of Economic Research.

Holling, C.S. (1973). Resilience and stability of ecological systems. Annual Review of Ecology and Systematics, 4: 1-23.

Kawalcovid19. (2020) Kasus Covid-19 di Indonesia. Diakses dari Kawalcovid19.id https://experience.arcgis.com/experience/bf4eb5d76e98423c865678e32c8937d4

Levin, S. A., Barrett, S., Aniyar, S., Baumol, W., Bliss, C., Bolin, B., ... \& Sheshinski, E. (1998). Resilience in natural and socioeconomic systems. Environment and development economics, 3(2), 221-262.

Lindell, M., \& Prater, C. (2003). Assessing community impacts of natural disasters. Natural Hazards Review, 4(4), 176-185.

Martin, A., Markhvida, M., Hallegatte, S., \& Walsh, B. (2020). Socio-economic impacts of COVID-19 on household consumption and poverty. Economics of disasters and climate change, 4(3), 453-479. https://doi.org/10.1007/s41885-020-00070-3

Pelling, M., Ozerdem, A., \& Barakat, S. (2002). The macro-economic of disasters. Progress in Development Studies, 2(4), 283-305.

Smith, J. A., \& Judd, J. (2020). COVID-19: Vulnerability and the power of privilege in a pandemic. Health Promotion Journal of Australia, 31(2), 158-160. https://doi.org/10.1002/ hpja.333

Strauss, J., Witoelar, F., \& Sikoki, B. (2016). The fifth wave of the Indonesia family life survey: overview and field report (Vol. 1). Santa Monica: CA:RAND.

Standing, G. (2014). The Precariat-The new dangerous class. Amalgam, 6(6-7), 115-119.

Sumner, A., Hoy, C., \& Ortiz-Juarez, E. (2020). Estimates of the impact of COVID-19 on global poverty. Unuwider, (April), 1-9. https://doi.org/10.35188/UNU-WIDER/2020/800-9

Tribunnews. (2020). Khofifah Salurkan Rp 330 Miliar Kredit Dagulir untuk Pemulihan Ekonomi di Jatim Akibat Pandemi Covid. Retrieved from https://surabaya.tribunnews.com/: https://surabaya.tribunnews.com/2020/09/08/khofifah-salurkan-rp-330-miliar-kredit-dagulir-untuk-pemulihan-ekonomi-di-jatim-akibat-pandemi-covid

Suryahadi, A., Al Izzati, R., \& Suryadarma, D. (2020). The Impact of COVID-19 Outbreak on Poverty: An. SMERU Working Paper.

The Lancet. (2020). Redefining vulnerability in the era of COVID-19. The Lancet, 395(10230), 1089. https://doi.org/10.1016/S0140-6736(20)30757-1

Walker, B.H., Holling, C.S., Carpenter, S.R. \& Kinzig, A.P. (2004). Resilience, adaptability and transformability in social-ecological systems. Ecology and Society, 9(2), 5. Available at: www.ecologyandsociety.org/vol9/iss2/art5/.

Voa Indonesia. (2020). Pemberdayaan Perempuan Kelompok Rentan di Tengah Pandemi. Retrieved from /www.voaindonesia.com: https://www.voaindonesia.com/a/pemberdayaan-perempuan-kelompok-rentan-di-tengah-pandemi/5477756.html

Worldometer. (2020). Covid-19 Coronavirus Pandemic. Retrieved from Worldometer.info: https://www.worldometers.info/coronavirus/ 